\title{
Effect of Udder Health Status and Lactation Phase on the Characteristics of Sardinian Ewe Milk
}

\author{
L. Bianchi, ${ }^{1}$ A. Bolla, $\dagger^{2}$ E. Budelli, ${ }^{3}$ A. Caroli, ${ }^{4}$ \\ C. Casoli, ${ }^{1}$ M. Pauselli, ${ }^{1}$ and E. Duranti ${ }^{1}$ \\ 'Dipartimento di Scienze Zootecniche, \\ Università degli Studi di Perugia, 06121 Perugia, Italy \\ ${ }^{2}$ Redhan Institute Srl., 06034 Foligno (Perugia), Italy \\ ${ }^{3}$ Fondazione Parco Tecnologico Padano, \\ Centro Ricerche e Studi Agroalimentari, 20090 Segrate (Milano), Italy \\ ${ }^{4}$ Dipartimento di Sanità e Benessere Animale, \\ Università di Bari, 70010 Valenzano (Bari), Italy
}

\begin{abstract}
Mammary involution and inflammation are known to negatively affect milk quality. A trial was carried out to elucidate the mechanism by which udder health status and lactational phase determine compositional modifications in ovine milk. A total of 60 individual milk samples was collected from a group of 20 pluriparous Sardinian ewes from mid to late lactation. Each sample was assessed for its chemical characteristics, quantitative distribution of casein fractions, lactodynamographic characteristics, and enzymatic activity. Udders were classed as healthy, doubtful, or infected on the basis of repeated somatic cell counts, and samples were grouped in 3 classes of days in milk. Results indicated that both udder inflammation and mammary involution can increase plasmin (PL) activity (15.6 vs. $18.4 \mathrm{U} / \mathrm{mL}$ in healthy vs. infected udders; 14.0 vs. $20.2 \mathrm{U} / \mathrm{mL}$ in phase 1 vs. 3), which is responsible for an evident protein breakdown in milk. Significant differences between groups were observed for several characteristics. With regard to udder heath status, casein index was lower in the infected vs. healthy udders ( 74.8 vs. $76.6 \%)$, and $\beta_{\text {tot }}$-casein showed a similar trend $(43.9$ vs. $46.6 \%)$. As a consequence of protein degradation, $\gamma$-casein $(5.78 \mathrm{vs}$. $2.82 \%)$ and proteolysis index (7.60 vs. 3.82 ) increased in the infected group with respect to the healthy group. Udder health status also affected milk technological traits. Udder inflammation resulted in longer clotting time (20.7 vs. $16.5 \mathrm{~min}$ for infected vs. healthy, respectively) and in poorer curd firmness (35.6 vs. $47.6 \mathrm{~mm}$ for infected vs. healthy, respectively). Frequency of samples reactive to rennet was 100,93 , and $67 \%$, respectively, for healthy, doubtful, and infected groups. With regard to lactational phase, a decrease in $\alpha_{\mathrm{s} 1^{-}}$
\end{abstract}

Received January 27, 2004.

Accepted April 7, 2004

Corresponding author: E. Duranti; e-mail: duranti@unipg.it. casein (39.13 vs. $29.36 \%$ ) and $\beta_{1}$-casein (23.41 vs. $19.36 \%$ ) occurred during phase 1 vs. 3 , whereas $\kappa+$ $\alpha_{\mathrm{s} 2}$-casein increased (12.30 vs. $21.56 \%$, phase 1 vs. 3 ). Correlation coefficients confirmed the role of PL in protein degradation. It was concluded that PL activity was strongly affected by both lactational phase and udder health status and, in turn, could be an important agent enhancing milk quality detriment.

(Key words: ewe milk, somatic cell count, lactational phase, plasmin activity)

Abbreviation key: PA = plasminogen activator, $\mathbf{P G}=$ plasminogen, $\mathbf{P A I}=$ plasminogen activator inhibitors, $\mathbf{P L}=$ plasmin .

\section{INTRODUCTION}

Mammary gland involution is an example of cellular remodeling (i.e., a dynamic modification) that involves the adult animal and changes the structure of this gland (Fantuz and Baldi, 1997; Furth et al., 1997; Guenette, 1997). Cellular involution can be initiated by 3 events: reduction in the number of cytoplasm organelles, particularly those involved in protein synthesis (rough endoplasmic reticulum and Golgi apparatus); reduction in the number of secreting structures (vesicles and microtubules); and disruption of epithelial tight junctions, with subsequent onset of a paracellular flow (Holst et al., 1987; Stelwagen et al., 1994; Shamay et al., 2002). During this process, wide ultrastructural changes involving the mammary gland (Capuco and Akers, 1999) take place, as do changes in milk composition (Wilde et al., 1999), particularly the decrease in CN, $\alpha$-lactoalbumin, and $\beta$-lactoglobulin (Aslam and Hurley, 1997; Mara et al., 1998; Coker et al., 1999). As a result, milk production decreases and its qualitative and technological characteristics worsen (Fox, 1981, 1982; Bastian et al., 1991; Baldi et al., 2002).

This process is regulated by proteolytic enzymes, first of all by the plasmin (PL)-plasminogen (PG) system, 
whose mechanism of activity is well known, and has been widely reviewed in the bovine (Baldi et al., 1996; Bastian and Brown, 1996; Saint-Denis et al., 2001).

Plasmin (EC 3.4.21.7) concentration in milk, and that of $\mathrm{PG}$, its inactive precursor, is subject to considerable variations, depending mainly on different physiological factors (stage of lactation, parity, etc.; Kelly et al., 1998; Monks et al., 2002), but also on udder health status (i.e., mastitis; Le Roux et al., 1995a,b) and nutrition (Nicholas et al., 1996; Bugaud et al., 2001).

Because little is known about the involution process within the mammary gland in the ovine (Baldi et al., 1997; Casoli et al., 1999), it is important to study further the variability of the complex PL-PG system in ovine milk. The present work focuses on the second part of the lactational phase, when milk is known to undergo major modifications that often result in its detrimental quality. In particular, variations in activities of PL, PG, and plasminogen activator (PA) were evaluated with regard to lactational phase and SCC. Moreover, quantitative distribution of $\mathrm{CN}$ fractions and the relationships between them, were assessed in addition to the enzymatic complex and milk lactodynamographic characteristics.

\section{MATERIALS AND METHODS}

\section{Animals and Samplings}

Twenty pluriparous Sardinian ewes that had lambed between late January and early February were selected from a commercial flock of 250 adult ewes reared in low hill areas of central Apennine Italy. Average milk yield of the flock was $221 \pm 54 \mathrm{~kg}$ during $208 \pm 22 \mathrm{~d}$ of lactation. During the trial, ewes were allowed to graze native pastures from 0800 to $1730 \mathrm{~h}$ and were housed indoors overnight in free stalls. Diet was supplemented with alfalfa hay (ad libitum) and a concentrate (400 g/ d) composed of $33 \%$ barley grain, $33 \%$ oat grain, and $33 \%$ corn grain. After weaning ( $48 \pm 11 \mathrm{~d}$ from lambing), all ewes were milked twice daily at 0730 and $1730 \mathrm{~h}$ using a milking machine (43 kPa; 150 pulsations/min). Milk samples were collected 3 times from each ewe at regular intervals from $90 \pm 13$ to $157 \pm 16$ DIM during May to July. A total of 60 samples were collected. Udders were milked by hand, $\mathrm{pH}$ was recorded, and samples were refrigerated and taken to the laboratory within $2 \mathrm{~h}$ for further analyses. No preservatives were added.

\section{Chemical Analysis}

Milk samples were assessed for fat and lactose (Milkoscan 6000 FT supplied by Foss Electric, Hilleröd, Denmark); titratable acidity, expressed as degree Sox-
hlet-Henkel ( $\left.{ }^{\circ} \mathrm{SH} / 100 \mathrm{~mL}\right)$, calcium (FIL-IDF, 1992); phosphorus (FIL-IDF, 1990); chlorides (CharpentierVolhard method); CP (total nitrogen $\times 6.38$; FIL-IDF, 1993); and CN content (FIL-IDF, 1964). The CN index was calculated as $\mathrm{CN} / \mathrm{CP} \times 100$.

\section{Casein Fractions}

The following $\mathrm{CN}$ fractions were determined: $\alpha_{\mathrm{s} 1}$-ca-

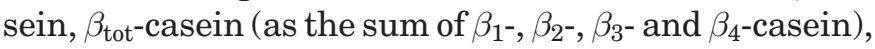
$\kappa+\alpha_{\mathrm{s} 2}$-casein, and $\gamma$-casein. Phenotyping of milk samples was carried out by isoelectric focusing in ultrathin polyacrylamide gels $(250 \times 111 \times 0.3 \mathrm{~mm})$ using the method of Erhardt et al. (1998) with some modification. Briefly, screening gels with $8 M$ urea contained $1.027 \%$ (wt/vol) Pharmalyte at $\mathrm{pH} 2.5$ to 5 (Amersham Biosciences Europe, Freiburg, Germany); 0.342\% (wt/vol) Pharmalyte at $\mathrm{pH} 4.2$ to $4.9 ; 0.342 \%$ (wt/vol) Pharmalyte at $\mathrm{pH} 4.6$ to $5 ; 0.342 \%$ (wt/vol) Pharmalyte at $\mathrm{pH}$ 4.5 to 5.4; and $0.342 \%$ (wt/vol) Pharmalyte at $\mathrm{pH} 5.0$ to 6.0. Subsequent quantitative estimation was performed using TDS Quantity One (Biorad, Philadelphia, PA) software.

The proteolysis index was calculated as the ratio of the percentage of $\gamma$-casein to the percentage of $\alpha_{\mathrm{s} 1}$-ca-

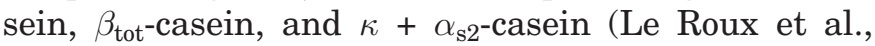
1995a).

\section{Curd Characteristics}

Milk lactodynamographic characteristics were measured for each sample at $35^{\circ} \mathrm{C}$ with a Maspress apparatus (Foss Italia, Padua, Italy) that illustrates by trace the development of viscosity in $10 \mathrm{~mL}$ of milk after addition of $200 \mu \mathrm{L}$ of a $0.8 \% \mathrm{vol} / \mathrm{vol}$ solution of bovine rennet (titration 1:15,000, supplied by Chr. Hansen Italia, Corsica-Milan, Italy) in distilled water. No $\mathrm{pH}$ adjustment was carried out before analysis. Clotting time is the time from rennet addition to the beginning of coagulation, firming time is the time needed for the amplitude to reach $20 \mathrm{~mm}$ on the recording chart, and curd firmness is the amplitude of the trace 30 min after rennet addition (Zannoni and Annibaldi, 1981).

\section{Somatic Cell Count}

Total SCC was performed $24 \mathrm{~h}$ after samplings, according to FIL-IDF (1995), using a Fossomatic 5000 (Foss Electric). This trait also was expressed as a linear score (linear score $=\log _{2}$ [SCC/12,500]; Ali and Shook, 1980). Furthermore, udder health status was monitored using a decision rule that was based on repeated SCC, as proposed by Bergonier et al. (1999). An udder was assumed to be healthy when each SCC was 
$<500,000$ cells $/ \mathrm{mL}$, infected when at least $2 \mathrm{SCC}$ were $>1$ million cell $\mathrm{s} / \mathrm{mL}$, and doubtful in the remaining cases. This method had shown high efficiency (74.5\%) and specificity ( $>80 \%$ ) for detection of mastitis, and permitted us to take into account the noninfectious variation factors and the dynamics of infection.

\section{Determination of Enzymatic Activities}

Activities of PL, PG, and PA were determined with a method described by Baldi et al. (1996). Determination of PL activity was performed in duplicate in 96well microplates containing $220 \mu \mathrm{L}$ of $0.1 M$ Tris-HCl buffer ( $\mathrm{pH}$ 7.4), $0.6 \mathrm{~m} M$ Val-Leu-Lys-p-nitroanilide (V7127; Sigma Chemical Co., St. Louis, MO), and $30 \mu \mathrm{L}$ of sample. For PG assay, 30 plough units of urokinase (U8627; Sigma Chemical Co.) was added to the reaction mixture to obtain the complete activation of the proenzyme. For the determination of PA, $2 \mu \mathrm{L}$ of sample was added to $250 \mu \mathrm{L}$ of a reaction mixture containing 0.1 $M$ Tris- $\mathrm{HCl}$ buffer ( $\mathrm{pH}$ 8.0), $0.6 \mathrm{~m} M$ Val-Leu-Lys- $p$ nitroanilide, and $50 \mu \mathrm{g} / \mathrm{mL}$ plasminogen (P5661; Sigma Chemical Co.). In all cases, an analysis in which samples were replaced by buffer was used as a control to detect spontaneous breakdown of the substrate. Reaction mixtures were incubated at $37^{\circ} \mathrm{C}$ for $3 \mathrm{~h}$ and absorbance at $405 \mathrm{~nm}$ was measured in 30-min intervals with a microplate reader (DV 990 BV 4/6; Gio. De Vita \& Co., Rome, Italy). Rate of $p$-nitroanilide formation was measured from the linear portion of the absorbance vs. time curve. Plasminogen was calculated as the difference between total activity and PL activity. Plasmin, PG, and PA values were expressed as units, one unit being the amount of enzyme that produces a change in absorbance at $405 \mathrm{~nm}$ of 0.1 unit in $60 \mathrm{~min}$.

\section{Statistical Analyses}

All data were analyzed using the PROC MIXED (SAS Inst., Inc., Cary, NC) according to the following linear model:

$$
\mathrm{Y}_{\mathrm{ijkl}}=\mu+\alpha_{\mathrm{i}}+\beta_{\mathrm{j}}+\delta_{\mathrm{ik}}+\varepsilon_{\mathrm{ijkl}}
$$

where $\mathrm{Y}_{\mathrm{ijkl}}=$ dependent variable, $\mu=$ overall mean, $\alpha_{\mathrm{i}}=$ udder status (healthy, doubtful, or infected), $\beta_{\mathrm{j}}=$ lactational phase $(1=90 \pm 13 \mathrm{DIM} ; 2=121 \pm 12 \mathrm{DIM}$; $3=157 \pm 16$ DIM), $\delta_{\mathrm{ik}}=$ random effect of ewe within udder status, and $\varepsilon_{\mathrm{ijkl}}=$ residual error term. The interaction between udder health status and lactational phase was not significant, so it was not included in the model.

Samples were further classified as either reactive or nonreactive on the basis of their response to rennet addition. The PROC LOGISTIC (SAS Inst., Inc.) was used to evaluate the effect of udder status and lactational phase on rennet reactivity. Moreover, the correlation coefficients between the given variables were calculated using the PROC CORR (SAS Inst., Inc.).

\section{RESULTS AND DISCUSSION}

\section{Udder Health Status}

Results summarized in Table 1 show the effects of udder health status and lactational phase on milk composition. With regard to health status, $\mathrm{pH}$ and $\mathrm{Ca}$ content were greater $(P<0.05)$ in milk from infected udders than in healthy or doubtful udders. Furthermore, a nonsignificant increase in $\mathrm{Cl}^{-}$was observed for infected udders, confirming the observations of other authors in the case of high-SCC milk (Le Roux et al., 1995a; Mariani et al., 1999).

Compared with healthy and doubtful udders, milk samples from infected udders had less lactose $(P<0.05$; infected vs. doubtful) and fat $(P<0.05$; infected vs. healthy) content, suggesting impaired secretory function.

Health status also had a remarkable effect on milk nitrogen compounds and protein quality. Samples from the infected and doubtful glands had greater $(P<0.05)$ $\mathrm{CP}$ content than did samples from healthy udders. Casein values were lower $(P<0.05)$ in healthy udders compared with doubtful and infected glands. Nevertheless, CN index was greater $(P<0.05)$ in samples from healthy vs. infected udders, whereas it was intermediate in doubtful ones. These results, particularly those observed from doubtful and infected glands, could be related to different degrees of weakening in the bloodmilk barrier that allowed blood serum proteins and urea to pass into milk and thus decreased the relative content of CN. Casein was also subject to enhanced hydrolysis, which resulted in decreased $(P<0.05) \beta_{\text {tot }^{-}}$ and $\beta_{2}$-casein content and subsequently in increased $(P$ $<0.05) \gamma$-casein and proteolysis index values in infected udders compared with healthy ones.

A marked detriment in curd characteristics was detected in samples from infected vs. healthy glands, as highlighted by their differences in clotting times $(P<$ $0.05)$ and curd firmness $(P<0.05)$. Moreover, udder health status clearly affected the frequency of samples reactive to rennet, that were 100,93 , and $67 \%$, respectively, for samples from healthy, doubtful, and infected udders. This decreasing trend was found to be significant $(P<0.05)$ by logistic regression.

It may be argued that mammary gland inflammation causes major changes in mammary epithelium organization and function, as well as marked detrimental effects on $\mathrm{CN}$ content and quality, according to Moussaoui et al. (2002) in the case of experimentally induced mas- 


\begin{tabular}{|c|c|c|c|c|c|c|}
\hline \multirow[b]{2}{*}{ Item } & \multicolumn{3}{|c|}{ Udder health status } & \multicolumn{3}{|c|}{ Lactational phase (DIM) } \\
\hline & Healthy & Doubtful & Infected & $90 \pm 13$ & $121 \pm 12$ & $157 \pm 16$ \\
\hline No. of observations & 24 & 18 & 18 & 20 & 20 & 20 \\
\hline \multicolumn{7}{|l|}{ Chemical analysis } \\
\hline $\mathrm{pH}$ & $6.55^{\mathrm{a}} \pm 0.020$ & $6.53^{\mathrm{a}} \pm 0.025$ & $6.63^{\mathrm{b}} \pm 0.021$ & $6.58 \pm 0.028$ & $6.54 \pm 0.019$ & $0.58 \pm 0.039$ \\
\hline Acidity, ${ }^{\circ} \mathrm{SH}$ & $10.28 \pm 0.208$ & $9.51 \pm 0.228$ & $9.24 \pm 0.211$ & $9.02^{\mathrm{a}} \pm 0.189$ & $9.64^{\mathrm{b}} \pm 0.245$ & $10.37^{\mathrm{b}} \pm 0.291$ \\
\hline Lactose, \% & $4.65^{\mathrm{ab}} \pm 0.056$ & $4.80^{\mathrm{b}} \pm 0.065$ & $4.51^{\mathrm{a}} \pm 0.059$ & $4.98^{\mathrm{c}} \pm 0.078$ & $4.80^{\mathrm{b}} \pm 0.053$ & $4.17^{\mathrm{a}} \pm 0.098$ \\
\hline Fat, $\%$ & $7.06^{b} \pm 0.225$ & $6.32^{\mathrm{ab}} \pm 0.264$ & $6.16^{\mathrm{a}} \pm 0.240$ & $4.52^{\mathrm{a}} \pm 0.316$ & $6.36^{\mathrm{b}} \pm 0.215$ & $8.66^{\mathrm{c}} \pm 0.395$ \\
\hline Calcium, \% & $0.219^{\mathrm{a}} \pm 0.004$ & $0.238^{\mathrm{ab}} \pm 0.005$ & $0.239^{\mathrm{b}} \pm 0.005$ & $0.226 \pm 0.006$ & $0.238 \pm 0.004$ & $0.232 \pm 0.008$ \\
\hline Phosphorus, \% & $0.127 \pm 0.008$ & $0.139 \pm 0.010$ & $0.143 \pm 0.008$ & $0.143 \pm 0.010$ & $0.140 \pm 0.007$ & $0.125 \pm 0.015$ \\
\hline Chloride, \% & $0.187 \pm 0.011$ & $0.187 \pm 0.014$ & $0.197 \pm 0.011$ & $0.180 \pm 0.015$ & $0.182 \pm 0.010$ & $0.209 \pm 0.021$ \\
\hline Crude protein, $\%$ & $5.47^{\mathrm{a}} \pm 0.106$ & $6.00^{\mathrm{b}} \pm 0.132$ & $5.95^{\mathrm{b}} \pm 0.109$ & $5.52^{\mathrm{a}} \pm 0.144$ & $5.95^{\mathrm{b}} \pm 0.098$ & $5.95^{\mathrm{b}} \pm 0.202$ \\
\hline Casein, \% & $4.18^{\mathrm{a}} \pm 0.084$ & $4.56^{\mathrm{b}} \pm 0.103$ & $4.45^{\mathrm{b}} \pm 0.085$ & $4.11^{\mathrm{a}} \pm 0.115$ & $4.51^{\mathrm{b}} \pm 0.764$ & $4.57^{\mathrm{b}} \pm 0.158$ \\
\hline Casein index ${ }^{1}, \%$ & $76.63^{\mathrm{b}} \pm 0.444$ & $76.11^{\mathrm{ab}} \pm 0.544$ & $74.77^{\mathrm{a}} \pm 0.451$ & $74.96 \pm 0.608$ & $75.86 \pm 0.404$ & $76.68 \pm 0.835$ \\
\hline \multicolumn{7}{|l|}{ Casein fractions } \\
\hline$\alpha_{\mathrm{s} 1}$ casein, $\%$ & $32.25 \pm 1.786$ & $34.27 \pm 2.223$ & $34.34 \pm 1.842$ & $39.13^{b} \pm 2.429$ & $32.47^{\mathrm{a}} \pm 1.653$ & $29.36^{\mathrm{a}} \pm 3.416$ \\
\hline$\beta_{\text {tot }}$-casein, \% & $46.55^{\mathrm{b}} \pm 0.826$ & $44.60^{\mathrm{ab}} \pm 1.028$ & $43.85^{\mathrm{a}} \pm 0.852$ & $43.20 \pm 1.223$ & $45.62 \pm 0.764$ & $45.58 \pm 1.579$ \\
\hline$\beta_{1}, \%$ & $21.88 \pm 0.844$ & $21.67 \pm 1.051$ & $19.64 \pm 0.871$ & $23.41^{\mathrm{b}} \pm 1.148$ & $19.42^{\mathrm{a}} \pm 0.782$ & $19.36^{\mathrm{a}} \pm 1.615$ \\
\hline$\beta_{2}, \%$ & $16.43^{\mathrm{b}} \pm 0.326$ & $16.17^{\mathrm{ab}} \pm 0.406$ & $15.36^{\mathrm{a}} \pm 0.337$ & $15.50 \pm 0.444$ & $16.28 \pm 0.302$ & $16.56 \pm 0.624$ \\
\hline$\beta_{3}, \%$ & $4.97 \pm 0.500$ & $4.27 \pm 0.623$ & $5.32 \pm 0.516$ & $2.74^{\mathrm{a}} \pm 0.681$ & $6.05^{\mathrm{b}} \pm 0.463$ & $5.78^{\mathrm{b}} \pm 0.957$ \\
\hline$\beta_{4}, \%$ & $3.27 \pm 0.397$ & $2.49 \pm 0.494$ & $3.53 \pm 0.409$ & $1.55^{\mathrm{a}} \pm 0.540$ & $3.86^{\mathrm{b}} \pm 0.377$ & $3.88^{\mathrm{b}} \pm 0.759$ \\
\hline$\kappa+\alpha_{\mathrm{s} 2}$-casein, $\%$ & $18.27 \pm 1.225$ & $17.52 \pm 1.525$ & $16.02 \pm 1.264$ & $12.30^{\mathrm{a}} \pm 1.666$ & $17.96^{\mathrm{b}} \pm 1.134$ & $21.56^{\mathrm{b}} \pm 2.234$ \\
\hline$\gamma$-casein, \% & $2.82^{\mathrm{a}} \pm 0.763$ & $3.60^{\mathrm{ab}} \pm 0.950$ & $5.78^{\mathrm{b}} \pm 0.787$ & $5.37 \pm 1.038$ & $3.95 \pm 0.707$ & $3.50 \pm 1.460$ \\
\hline Proteolysis index ${ }^{2}$ & $3.82^{\mathrm{a}} \pm 1.050$ & $4.74^{\mathrm{ab}} \pm 1.304$ & $7.60^{\mathrm{b}} \pm 1.081$ & $5.67 \pm 1.424$ & $5.21 \pm 0.970$ & $3.41 \pm 2.004$ \\
\hline \multicolumn{7}{|l|}{ Curd parameters } \\
\hline Clotting time, min & $16.52^{\mathrm{a}} \pm 0.98$ & $19.12^{\mathrm{ab}} \pm 1.15$ & $20.67^{\mathrm{b}} \pm 1.18$ & $20.72 \pm 1.40$ & $18.75 \pm 0.90$ & $16.83 \pm 2.05$ \\
\hline Firming time, $\min$ & $1.80 \pm 0.35$ & $1.58 \pm 0.40$ & $1.55 \pm 0.45$ & $1.43 \pm 0.52$ & $1.78 \pm 0.32$ & $1.70 \pm 0.72$ \\
\hline Curd firmness, mm & $47.63^{\mathrm{b}} \pm 2.018$ & $36.63^{\mathrm{b}} \pm 2.353$ & $35.60^{\mathrm{a}} \pm 2.400$ & $38.04^{\mathrm{a}} \pm 2.862$ & $46.79^{\mathrm{b}} \pm 1.833$ & $45.03^{\mathrm{b}} \pm 2.195$ \\
\hline \multicolumn{7}{|l|}{ Cellular count } \\
\hline Linear score & $4.19^{\mathrm{a}} \pm 0.380$ & $4.85^{\mathrm{a}} \pm 0.467$ & $7.55^{\mathrm{b}} \pm 0.402$ & $4.83^{\mathrm{a}} \pm 0.517$ & $4.99^{\mathrm{a}} \pm 0.361$ & $6.77^{\mathrm{b}} \pm 0.647$ \\
\hline \multicolumn{7}{|l|}{ Enzymatic activity } \\
\hline Plasmin, U/mL & $15.60^{\mathrm{a}} \pm 0.819$ & $15.96^{\mathrm{ab}} \pm 0.988$ & $18.35^{\mathrm{b}} \pm 0.841$ & $14.01^{\mathrm{a}} \pm 1.083$ & $15.63^{\mathrm{a}} \pm 0.741$ & $20.20^{b} \pm 1.582$ \\
\hline Plasminogen, U/mL & $27.30 \pm 0.730$ & $26.85 \pm 0.881$ & $26.31 \pm 0.750$ & $29.69^{\mathrm{b}} \pm 0.965$ & $25.99^{\mathrm{a}} \pm 0.661$ & $24.79^{\mathrm{a}} \pm 1.414$ \\
\hline Plasminogen/plasmin & $1.82 \pm 0.117$ & $1.89 \pm 0.141$ & $1.54 \pm 0.120$ & $2.40^{\mathrm{c}} \pm 0.155$ & $1.77^{\mathrm{b}} \pm 0.106$ & $1.08^{\mathrm{a}} \pm 0.226$ \\
\hline Plasminogen activator, $\mathrm{U} / \mathrm{mL}$ & $547.68^{\mathrm{b}} \pm 25.715$ & $538.04^{\mathrm{b}} \pm 31.416$ & $419.56^{\mathrm{a}} \pm 26.402$ & $342.70^{\mathrm{a}} \pm 34.292$ & $551.85^{\mathrm{b}} \pm 23.503$ & $610.72^{\mathrm{b}} \pm 48.319$ \\
\hline
\end{tabular}

${ }^{\mathrm{a}, \mathrm{b}, \mathrm{c}}$ Subcolumns means within udder health status and lactational phase with different superscripts differ, $P<0.05$.

${ }^{1}$ Calculated as the ratio of casein to crude protein.

${ }^{2}$ Calculated as the ratio of $\gamma$-casein to $\alpha_{\mathrm{s} 1^{-}}, \beta_{\text {tot }}$ and $\kappa+\alpha_{\mathrm{s} 2^{-}}$casein. 
titis. Linear scores did not differ between healthy and doubtful ewes, but both groups had better $(P<0.05)$ scores than infected ewes. Doubtful health status of udders probably occurred in response to transitory udder inflammations, resulting in somewhat intermediate milk properties. These properties often did not differ from those of healthy glands. Further investigation of the variation in total and differential cell counts could contribute to understanding the degree of severity of mammary inflammations. These findings are consistent with an increase in PL activity, an enzyme that is responsible for $\mathrm{CN}$ breakdown (Bastian and Brown, 1996) and tight junctions disruption (Shamay et al., 2002 , 2003). In the present study, milk from infected glands had greater $(P<0.05)$ PL activity than that from healthy glands, according to the observations reported for sheep's milk (Casoli et al., 1999; Chiofalo et al., 1999) and cow's milk (Le Roux et al., 1995a). Activity of PG, however, was not different among health status groups, so it could be concluded that the greater PL values observed in the infected glands may be due to increasing enzyme quantities bypassing the blood-milk barrier rather than to increasing activation of PG. Surprisingly, PA activity was less $(P<0.05)$ in milk from infected glands compared with the other health statuses, in contrast to observations of Heegaard et al. (1994a) in cows and of Leitner et al. (2004) in ewe's milk. In the present work, the results do not clarify this phenomenon, but an involvement of plasminogen activator inhibitors (PAI) could be the result of 2 considerations. The PAI represent an important fraction of blood serum proteins (van Gent et al., 2003) and could therefore have entered the mammary gland during an inflammatory episode because of the above-mentioned disruption of tight junctions and epithelial damage. Second, PAI belong to the serine protease inhibitors (serpins) group, and as such, have a peculiar mechanism of action that consists of the formation of a covalent serpin-protease complex, with the subsequent irreversible inhibition of both the protease and its inhibitor (Ye and Goldsmith, 2001). This mechanism could be regarded at as a defense against excessive proteolysis. For example, it is well known that pathogenic microflora can bind and thus enhance PG activation on their surface. Pathogens can therefore increase their virulence by using the proteolytic activity of PL for tissue invasion (Bergmann et al., 2003; Crowe et al., 2003).

\section{Lactational Phase}

Values of $\mathrm{pH}$ remained within the physiological range for sheep milk, whereas titratable acidity increased $(P$ $<0.05)$ as lactation advanced, suggesting a higher con- tent of molecules with buffering activity, such as CN (Alais, 1984). Lactose content tended to decrease with advancing lactation $(P<0.05)$, whereas fat, $\mathrm{CP}$, and $\mathrm{CN}$ concentrations increased $(P<0.05)$ with advancing DIM. As expected during advancing lactation, lower milk production was associated with a progressive increase $(P<0.05)$ in concentrations of milk fat and proteins. Lactational phase also determined some modifications of $\mathrm{CN}$ fractions distribution. In fact, the concentration of $\alpha_{\mathrm{s} 1}$-casein decreased $(P<0.05)$ from 39.13 to $29.36 \%$ as lactation advanced. Furthermore, although concentration of $\beta_{\text {tot }}$-casein did not differ as lactation advanced, the percentage of the most important fraction $\left(\beta_{1}\right.$-casein $)$ decreased $(P<0.05)$, whereas that of the most degraded fractions ( $\beta_{3}$-casein and $\beta_{4}$-casein) increased $(P<0.05)$. Lastly, compared with earlier lactation, percentages of $\kappa+\alpha_{\mathrm{s} 2}$-casein were greater $(P<$ $0.05)$ than during the latter stages of lactation. Frequencies of samples reactive to rennet tended to decrease from 100 to 93.5 and down to $85 \%$ respectively for the first, second, and third phase. This trend, however, was not significant when tested by logistic regression.

Among the lactodynamographic characteristics, curd firmness increased $(P<0.05)$ from the first to the last 2 periods, consistent with the greater $\mathrm{CN}$ content observed during late lactation. The SCC increased $(P<$ 0.05 ; expressed by the linear score) as lactation advanced.

Activity of PL increased $(P<0.01)$ from 14.01 to 20.20 $\mathrm{U} / \mathrm{mL}$ (phase 1 vs. 3), whereas PG activity and PG:PL ratio showed an opposite trend. These results confirm previous reports for milk from cows (Baldi et al., 1996) and sheep (Casoli et al., 1999). Activity of PA was less $(P<0.05)$ during early than later lactation. In physiological conditions, in fact, greater PA activities are usually associated with increased PL activity and PG conversion to PL (cattle, Baldi et al., 1996; goats, Fantuz et al., 2001). It must be noted, however, that PA constantly showed an excess of activity compared with that of PG, which alone could not explain PL variations. The precise mechanisms of plasminogen activation and its regulation must be taken into account. In the present case, for instance, it is interesting that progressively higher PL values were detected in correlation with increasing $\kappa+\alpha_{\mathrm{s} 2}$-casein concentrations during lactation. In the bovine, in fact, it was observed that $\kappa$-casein and $\alpha_{\mathrm{s} 2^{-}}$ casein represent a matrix for the activation of $P G$ within casein micelles (Heegaard et al., 1994b, 1997; Politis et al., 1994).

\section{Correlation Coefficients}

Correlation coefficients between the enzymatic activities, cellular counts, DIM, and different compositional 
Table 2. Correlation coefficients among enzymatic activities, linear score, DIM, and other traits.

\begin{tabular}{|c|c|c|c|c|c|c|}
\hline $\mathrm{n}=60$ & Plasmin & Plasminogen & $\begin{array}{l}\text { Plasminogen/ } \\
\text { plasmin }\end{array}$ & $\begin{array}{l}\text { Plasminogen } \\
\text { activator }\end{array}$ & Linear score & DIM \\
\hline Linear score & $0.65^{* *}$ & $-0.37 * *$ & $-0.60 * *$ & NS & $\ldots$ & $0.37 * *$ \\
\hline DIM & $0.44^{* *}$ & $-0.26^{*}$ & $-0.46^{* *}$ & $0.38^{* *}$ & $0.37 * *$ & $\ldots$ \\
\hline $\mathrm{pH}$ & $0.27 *$ & NS & $-0.24^{*}$ & NS & $0.49 * *$ & NS \\
\hline Crude protein & $0.25^{*}$ & $-0.29 *$ & $-0.34^{*}$ & NS & $0.49 * *$ & $0.44^{* *}$ \\
\hline Casein & $\mathrm{NS}$ & NS & $-0.30^{*}$ & NS & $0.36^{* *}$ & NS \\
\hline Casein index ${ }^{1}$ & NS & $0.28^{*}$ & NS & $0.41^{* *}$ & $-0.28 *$ & $0.32 *$ \\
\hline$\alpha_{\mathrm{s} 1}$-casein & $-0.43 * *$ & $0.30^{*}$ & $0.40^{* *}$ & $-0.29 *$ & NS & $-0.46^{* *}$ \\
\hline$\beta_{\text {tot }}$-casein & $-0.32^{*}$ & NS & $-0.33^{*}$ & $0.37 * *$ & NS & $0.32 *$ \\
\hline$\beta_{1}$ & NS & NS & NS & NS & $-0.32^{*}$ & $-0.31^{*}$ \\
\hline$\beta_{2}$ & NS & NS & $-0.23^{*}$ & $0.42^{* *}$ & NS & $0.24 *$ \\
\hline$\beta_{3}$ & $0.33 * *$ & $-0.27^{*}$ & $-0.33^{*}$ & NS & $0.39 * *$ & $0.55^{* *}$ \\
\hline$\beta_{4}$ & $0.26^{*}$ & $-0.26^{*}$ & $-0.29 *$ & NS & $0.36^{* *}$ & $0.50 * *$ \\
\hline$\kappa+\alpha_{\mathrm{s} 2}$-casein & $0.34^{* *}$ & $-0.26^{*}$ & $-0.35^{* *}$ & $0.36^{* *}$ & NS & $0.51^{* *}$ \\
\hline$\gamma$-casein & NS & NS & NS & $-0.34^{* *}$ & NS & NS \\
\hline Proteolysis index ${ }^{2}$ & $0.30 *$ & NS & NS & NS & NS & NS \\
\hline
\end{tabular}

parameters are presented in Table 2. Plasmin was positively correlated with linear scores $(P<0.01)$ and with DIM $(P<0.01)$, in agreement with observations of Benslimane et al. (1990), and to a lesser extent, with $\mathrm{pH}$ $(P<0.05)$, confirming results reported for bovine milk (Politis et al., 1989; Bastian et al., 1991).

Furthermore, PL was correlated positively $(P<0.05)$ with $\mathrm{CP}$, whereas no significant correlation was detected between PL and CN or CN index. When considering the single $\mathrm{CN}$ fractions, however, PL was correlated negatively with $\alpha_{\mathrm{s} 1}$-casein $(P<0.01)$ and $\beta_{\text {tot }}$-casein $(P$ $<0.05$ ), which are known to be subject to its proteolytic activity (Srinivasan and Lucey, 2002), and positively correlated with $\beta_{3}$-casein $(P<0.01), \beta_{4}$-casein $(\mathrm{P}<0.05)$, $\kappa+\alpha_{\mathrm{s} 2}$-casein $(P<0.01)$, and proteolysis index $(P<$ 0.05). These observations confirm the involvement of PL in the inflammatory process and during mammary involution as well as its role in $\mathrm{CN}$ degradation. As expected, correlation coefficients of PG and PG:PL were opposite those of PL for most of the characteristics tested.

With regard to PA, a positive and significant $(P<$ 0.01 ) correlation with DIM was observed, but a correlation with linear scores was not detected. Moreover, the relationship of PA with $\mathrm{CN}$ index and $\mathrm{CN}$ fractions is without explanation. These findings indicate that further investigation of the whole process of PG activation and the role of both PA and PAI in milk is needed in sheep as in other species (Baldi et al., 1996; Fantuz et al., 2001).

Correlation coefficients showed particularly interesting trends between linear scores and other variables such as DIM $(P<0.01)$ and $\mathrm{pH}(P<0.01)$. Furthermore, linear scores were correlated positively with $\mathrm{CP}(P<$ $0.01)$ and $\mathrm{CN}(P<0.01)$, but negatively with $\mathrm{CN}$ index $(P<0.05)$, which is in agreement with other reports (Seaman et al., 1988; Le Roux et al., 1995a). These authors indicated that the proteolytic processes observed in high-SCC milk are mainly due to the PL-PG system and to a lesser extent to other milk proteases. In particular, in the present work, the action of PL during udder inflammation may be confirmed by the negative correlation coefficient of linear score with $\beta_{1^{-}}$ casein $(P<0.05)$, whereas those with $\beta_{3}$-casein and $\beta_{4^{-}}$ casein were positive $(P<0.01)$.

The relationship between DIM and milk composition was apparent. In particular, DIM was correlated positively with $\mathrm{CP}(P<0.01)$ and $\mathrm{CN}$ index $(P<0.05)$ because of the progressive increase in milk constituent concentration as lactation advanced. Among $\mathrm{CN}$ fractions, negative correlation coefficients were observed between DIM and $\alpha_{\mathrm{s} 1}$-casein $(P<0.01)$ and $\beta_{1}$-casein $(P<0.05)$, whereas those with $\beta_{2}$-casein, $\beta_{3}$-casein, $\beta_{4^{-}}$ casein, and $\kappa+\alpha_{\mathrm{s} 2}$-casein were positive.

\section{CONCLUSIONS}

In the present work, SCC, associated with various udder health statuses, and lactational phase were evaluated to verify their role in milk quality with regard to its cheese-making properties. In particular, udder inflammation (indirectly diagnosed using SCC) and late lactation were associated with high PL activities in milk that, in turn, were responsible for marked proteolytic phenomena. Casein index was reduced in ewes with infected udders compared with milk from healthy ones. 
With regard to $\mathrm{CN}$ fractions, degradation of $\beta_{\text {tot }}$-casein was evident, and consequently $\gamma$-casein and proteolysis index were markedly increased. The most evident consequence of protein degradation in milk from infected udders was a significant decrease in the frequency of samples reactive to rennet. Secondly, milk from infected glands was associated negatively with curd characteristics. With regard to the lactational phase, it may be argued that PL markedly degraded $\alpha_{\mathrm{s} 1}$-casein and $\beta_{1^{-}}$ casein, whereas $\kappa+\alpha_{\mathrm{s} 2}$-casein, known to be less sensitive to the action of this enzyme, significantly increased. Curd traits seemed unaffected by lactational phase and curd firmness even increased as lactation advanced. It must be noted, however, that lactodynamographic characteristics are affected by other factors, such as protein concentration, so that the simple effect of casein degradation could be less evident. This scenario is confirmed by reported correlation coefficients. In fact, PL was correlated negatively with $\alpha_{\mathrm{s} 1}$-casein and $\beta_{\text {tot }}$-casein, but positively correlated with the more degraded $\beta$-casein components ( $\beta_{3}$-casein and $\beta_{4}$-casein) and with $\kappa+\alpha_{\mathrm{s} 2}$-casein.

The results highlight the effects of mammary inflammation and involution on milk spoilage, particularly on cheese-making properties. Both factors increased PL activity, which is responsible for the protein breakdown and, in turn, the decrease in rennet reactivity of milk. A different response of the PG activation system to udder inflammation and DIM was detected. In particular, a different trend of PA was observed among milk samples collected from glands of differing health status and lactational phase. The possible implication of different PAI concentration in milk is a presently unexplored field of research. Much work remains to understand the mechanisms by which mammary inflammation and involution affect milk production. In particular, it would be interesting to study the variability of leukocytes population that contribute to the SCC in milk, to evaluate the activity of proteases other than PL (of endogenous and bacterial origin), and to investigate the action of different pathogenic bacteria in mastitis development.

\section{ACKNOWLEDGMENTS}

Research supported by MURST contract year 2001, prot. 2001077279. The authors thank P. Lattaioli and G. Radici for their technical support.

\section{REFERENCES}

Alais, C. 1984. Science du lait. Principes des techniques laitières. SEPAIC, Paris.

Ali, A. K. A., and G. E. Shook. 1980. An optimum transformation for somatic cell concentration in milk. J. Dairy Sci. 63:487-490.
Aslam, M., and W. L. Hurley. 1997. Proteolysis of milk protein during involution of the bovine mammary gland. J. Dairy Sci. 80:2004-2010.

Baldi, A., V. Chiofalo, G. Savoini, R. Greco, F. Polidori, and I. Politis. 1997. Changes in plasmin and plasminogen activator activities in milk of late lactating ewes: Effects of bovine somatotropin treatment. Livest. Prod. Sci. 50:43-44.

Baldi, A., S. Modina, F. Cheli, F. Gandolfi, L. Pinotti, L. B. Scesi, F. Fantuz, and V. Dell'Orto. 2002. Bovine somatotropin administration to dairy goats in late lactation: Effects on mammary gland function, composition and morphology. J. Dairy Sci. 85:10931102.

Baldi, A., G. Savoini, F. Cheli, F. Fantuz, E. Senatore, L. Bertocchi, and I. Politis. 1996. Changes in plasmin, plasminogen, plasminogen activator system in milk from Italian Frisian herds. Int. Dairy J. 6:1045-1053.

Bastian, E. D., and R. J. Brown. 1996. Review article. Plasmin in milk and dairy products: An update. Int. Dary. J. 6:435-457.

Bastian, E. D., R. J. Brown, and C. A. Ernstrom. 1991. Plasmin activity and milk coagulation. J. Dairy Sci. 74:3677-3685.

Benslimane, S., M. J. Dognin-Bergeret, J. L. Berdague, and Y. Gaudemer. 1990. Variation with season and lactation of plasmin and plasminogen concentration in Montbeliard cow's milk. J. Dairy Res. 57:423-435.

Bergmann, S., D. Wild, O. Diekmann, R. Frank, D. Bracht, G. S. Chhatval, and S. Hammerschmidt. 2003. Identification of a novel plasmin(ogen) binding motif in surface displayed $\alpha$-enolase of Streptococcus pneumonite. Mol. Microbiol. 49:411-423.

Bergonier, D., G. Lagriffoul, F. Barillet, and X. Berthelot. 1999. Biologie et outils de dépistage des infections mammaires chez les ovins et les caprins. Pages 487-496 in Proc. Journées Nationales GTVINRA, Nantes, France.

Bugaud, C., S. Buchin, J. B. Coulon, A. Hauwuy, and D. Dupont. 2001. Influence of the nature of alpine pastures on plasmin activity, fatty acid and volatile compound composition of milk. Lait 81:401-414.

Capuco, A. V., and R. M. Akers. 1999. Mammary involution in dairy animals. J. Mammary Gland Biol. Neoplasia 4:137-144.

Casoli, C., E. Duranti, M. Pauselli, and A. Grandi. 1999. Factor affecting plasmin and plasminogen activity in ewe milk. Pages 531533 in Proc. XIII ASPA Cong. Franco Angeli, Milano, Italy.

Chiofalo, V., A. Baldi, G. Savoini, F. Polidori, V. Dell'Orto, and I. Politis. 1999. Response of dairy ewes in late lactation to recombinant bovine somatotropin. Small Rumin. Res. 34:119-125.

Coker, C. J., L. K. Creamer, R. G. Burr, and P. Hill. 1999. Hydrolysis of the $\alpha_{\mathrm{s} 1}$-casein $\mathrm{A}, \mathrm{B}$ and $\mathrm{C}$ variants by plasmin and chymosin. Int. Dairy J. 9:371-372.

Crowe, J. D., I. K. Sievwright, G. C. Auld, N. R. Moore, N. A. R. Gow, and N. Booth. 2003. Candida albicans binds human plasminogen: Identification of eight plasminogen-binding proteins. Mol. Microbiol. 47:1637-1651.

Erhardt, G., J. Juszczak, L. Panicke, and H. Krick-Saleck. 1998. Genetic polymorphism of milk proteins in Polish Red Cattle: A new genetic variant of $\beta$-lactoglobulin. J. Anim. Breed. Genet. 115:63-71.

Fantuz, F., and A. Baldi. 1997. La plasmina nel latte: Significato fisiologico e conseguenze sulla qualità. Latte 22:116-125.

Fantuz, F., F. Polidori, F. Cheli, and A. Baldi. 2001. Plasminogen activation system in goat milk and its relation with composition and coagulation properties. J. Dairy Sci. 84:1786-1790.

Fox, P. F. 1981. Proteinases in dairy technology. Neth. Milk Dairy J. 35:233-253.

Fox, P. F. 1982. Proteolysis in milk and dairy products. Bioc. Soc. Trans. 10:282-284.

Furth, P. A., U. Bar-Peled, and M. Li. 1997. Apoptosis and mammary gland involution: Reviewing the process. Apoptosys. 2:19-24.

Guenette, S. 1997. The role of growth factors and proteases in mammary gland involution. Pages 115-128 in Biological Signalling and the Mammary Gland. 2nd Hannah Symp. C. J. Wilde, M. Peaker, E. Taylor, ed. Ayr, UK.

Heegaard, C. W., P. A. Andreasen, T. E. Petersen, and L. K. Rasmussen. 1997. Dimeric $\alpha_{\mathrm{s} 2}$-casein, a novel matrix for tissue-type plas- 
minogen activator catalyzed plasminogen activation. Livest. Prod. Sci. 50:149-150.

Heegaard, C. W., T. Christensen, M. D. Rasmussen, C. Benfeldt, N. E. Jensen, K. Sejrsen, T. E. Petersen, and P. A. Andreasen. 1994a. Plasminogen activators in bovine milk during mastitis, an inflammatory disease. Fibrinolysis 8:22-30.

Heegaard, C. W., L. K. Rasmussen, and P. A. Andreasen. 1994b. The plasminogen activation system in bovine milk: Differential localization of tissue type plasminogen activator and urokinase in milk fractions is caused by binding to casein and urokinase receptor. Biochem. Biophys. Acta 122:45-55.

Holst, B. D., W. L. Hurley, and D. R. Nelson. 1987. Involution of the bovine mammary gland: Histological and ultrastructural changes. J. Dairy Sci. 70:935-944.

FIL-IDF. 1964. Determination of the casein content of milk. International Standard FIL-IDF 29. International Dairy Federation Brussels, Belgium.

FIL-IDF. 1990. Determination of total phosphorus content (Spectrometric method). International Standard FIL-IDF 42B. International Dairy Federation, Brussels, Belgium.

FIL-IDF. 1992. Determination of calcium content (Titrimetric method). International Standard FIL-IDF 36A. International Dairy Federation, Brussels, Belgium.

FIL-IDF. 1993. Determination of total nitrogen in milk. International Standard FIL-IDF 20B. International Dairy Federation, Brussels, Belgium.

FIL-IDF. 1995. Enumeration of somatic cells. International Standard FIL-IDF 148A. International Dairy Federation, Brussels, Belgium.

Kelly, A. L., S. Reid, P. Joyce, Y. W. J. Meaney, and J. Foley. 1998. Effect of decrease milking frequency of cows in late lactation on milk somatic cell count, polymorphonuclear leucocyte numbers, composition and proteolytic activity. J. Dairy Res. 65:365-373.

Leitner, G., M. Chaffer, A. Shamay, F. Shapiro, U. Merin, E. Ezra, A. Saran, and N. Silanikove. 2004. Changes in milk composition as affected by subclinical mastitis in sheep. J. Dairy Sci. 87:46-52.

Le Roux, Y., O. Colin, and F. Laurent. 1995a. Proteolysis in samples of quarter milk with varying somatic cell counts. 1 . Comparison of some indicator of endogenous preteolysis in milk. J. Dairy Sci. 78:1289-1298.

Le Roux, Y., J. M. Girardet, G. Humbert, F. Laurent, and G. Linden. 1995b. Proteolysis in samples of quarter milk with varying somatic cell counts. 2. Component PP3 and beta-casein 1P (f29105 and f29-107) of the proteose-peptone fraction. J. Dairy Sci. 78:1298-1305.

Mara, O., C. Roupie, A. Duffy, and A. L. Kelly. 1998. The curd forming properties of milk as affected by the action of plasmin. Int. Dairy J. 8:807-812.
Mariani, P., A. Summer, F. Martuzzi, and P. Formaggioni. 1999. Proteose peptone content in milk of Italian Brown cows with normal somatic cell values. Pages 519-521 in Proc. ASPA XIII Congr. Franco Angeli, Milano, Italy.

Monks, J., F. J. Geske, L. Lehman, and V. A. Fadok. 2002. Do inflammatory cells participate in mammary gland involution? J. Mammary Gland Biol. Neoplasia 7:163-176.

Moussaoui, F., I. Michelutti, Y. Le Roux, and F. Laurent. 2002. Mechanisms involved in milk endogenous proteolysis induced by a lipopolysaccharide experimental mastitis. J. Dairy Sci. 85:25622570.

Nicholas, G. D., C. G. Prosser, K. Stelwagen, and T. R. Mackle. 1996. Influence of level of feeding and lactational phase on proteolytic activity in bovine milk. Proc. N. Z. Soc. Anim. Prod. 56:114-117.

Politis, I., E. Lachance, E. Block, and J. D. Turner. 1989. Plasmin and plasminogen in bovine milk: A relationship with involution? J. Dairy Sci. 72:900-906.

Politis, I., J. K. White, K. O'Hare, B. Zavizion, J. Gilmore, and W. Caler. 1994. Distribution of plasminogen activator forms in in fractions of goat milk. J. Dairy Sci. 77:2900-2906.

Saint-Denis, T., G. Humbert, and J. L. Gaillard. 2001. Enzymatic assay for native plasmin, plasminogen and plasminogen activators in bovine milk. J. Dairy Res. 68:437-449.

Seaman, A. I., R. J. Verdi, D. M. Galton, and D. M. Barbano. 1988. Effect of mastitis on proteolytic activity in bovine milk. J. Dairy Sci. 71:505-512.

Shamay, A., F. Shapiro, G. Leitner, and N. Silanikove. 2003. Infusions of casein hydrolysates into the mammary gland disrupt tight junction integrity and induce involution in cows. J. Dairy Sci. 86:1250-1258.

Shamay, A., F. Shapiro, S. J. Mabjess, and N. Silanikove. 2002. Casein derived phosphopeptides disrupt tight junction integrity, and precipitously dry up milk secretion in goats. Life Sci. 70:2707-2719.

Srinivasan, M., and J. A. Lucey. 2002. Effects of added plasmin on the formation and rheological properties of rennet-induced skim milk gels. J. Dairy Sci. 85:1070-1078.

Stelwagen, K., S. R. Davis, V. C. Farr, C. G. Prosser, and R. A. Sherlock. 1994. Mammary epithelial tight junction integrity and mammary blood flow during an extended milking interval in goats. J. Dairy Sci. 77:426-432.

van Gent, D., P. Sharp, K. Morgan, and N. Kalsheker. 2003. Serpins: Structure, function and molecular evolution. Int. J. Biochem. Cell Biol. 35:1536-1547.

Wilde, C. J., C. H. Knight, and D. J. Flint. 1999. Control of milk secretion and apoptosis during mammary involution. J. Mammary Gland Biol. Neoplasia 4:129-136.

Ye, S., and E. J. Goldsmith. 2001. Serpins and other covalent protease inhibitors. Curr. Opin. Struct. Biol. 11:740-745.

Zannoni, M., and S. Annibaldi. 1981. Standardization of the rennet ability of milk by Formagraph-I. Sci. Tecn. Latt. Cas. 32:79-94. 